\title{
Eksplorasi Persepsi Ibu tentang Pendidikan Seks untuk Anak
}

\author{
Shofwatun Amaliyah, Fathul Lubabin Nuqul \\ UIN Maulana Malik Ibrahim, Jl. Gajayana No.50 Lowokwaru, Kota Malang \\ e-mail : shofwamaliyah@gmail.com
}

\begin{abstract}
Sex education is the provision of information about sex that aims to reduce the potential risk of sexual behavior. This effort is still taboo in the community, so parents feel hesitant to provide teaching about sex to children. The purpose of this study is to determine the perception of parents to sex education provided to children from an early age. This research was conducted in Jambesari village, Poncokusumo, Malang by using phenomenology approach and involving 5 mothers. The results show that parents perceive sex education as taboo, vulgar and inappropriate to convey to children, thus affecting the involvement and form of education provided by parents to children. The results also show that the need for the competence of sexual education is important to be done by parents.
\end{abstract}

Keywords: parent, sexual education, child

\begin{abstract}
Abstrak
Definisi pendidikan seks adalah pemberian informasi tentang seks yang bertujuan untuk mengurangi potensi risiko akibat perilaku seks yang negatif. Namun istilah tersebut masih asing di beberapa kalangan masyarakat, sehingga orangtua merasa ragu untuk memberikan pengajaran tentang seks kepada anak. Tujuan dari penelitian ini adalah untuk mengetahui persepsi orangtua terhadap pendidikan seks yang diberikan kepada anak sejak dini. Penelitian ini dilakukan di Desa Jambesari, Poncokusumo, Malang dengan menggunakan pendekatan fenomenologi dan melibatkan 5 orangtua (ibu) sebagai subjek penelitian. Hasil penelitian menunjukkan bahwa orangtua menganggap pendidikan seks sebagai hal yang tabu, vulgar dan tidak pantas untuk disampaikan kepada anak, sehingga berpengaruh terhadap keterlibatan dan bentuk pendidikan yang diberikan oleh orangtua kepada anak.
\end{abstract}

Kata Kunci: orangtua, pendidikan seks, anak

\section{Pendahuluan}

Maraknya pemberitaan tentang perilaku seks menyimpang, seperti pelecehan, sexual abuse, dan free sex menjadi ancaman bagi generasi muda, khususnya anak-anak yang masih kosong dalam pengetahuannya tentang seks. Berdasarkan data KPAI (Komisi Perlindungan Anak Indonesia) kasus sexual abuse mengalami peningkatan dalam kurun waktu 5 tahun terakhir.

Rendahnya kesadaran orangtua dalam memberikan perlindungan kepada anak, menjadi salah satu faktor penyebab meningkatnya kasus penyimpangan seks, seperti sexual abuse (Gatra, 2015). Dari hasil penelitian KPAI, $70 \%$ orangtua belum mampu mengasuh anak mereka menggu- nakan metode yang sesuai dengan perkembangan zaman sekarang (KPAI, 2016).

Pendidikan seks yang diberikan sejak dini mampu mengurangi potensi risiko yang timbul akibat perilaku seksual, seperti unwanted pregnancy dan penularan penyakit seksual, sehingga membantu meningkatkan kualitas hubungan yang positif pada anak (Odek, 2006).

Perlunya pendidikan seks bagi setiap individu tidak hanya untuk melindungi diri dari perilaku menyimpang seks, namun juga memberikan pemahaman kepada anak tentang batasan-batasan sebagai seorang laki-laki dan perempuan (Justicia, 2016). Akan tetapi, kenyataan yang ada di Indonesia saat ini orangtua masih menganggap pendidikan seks merupakan hal 
tabu untuk disampaikan kepada anak (Counterman dan Kirkwood, 2013).

Kebanyakan orangtua beranggapan bahwa pendidikan seks hanya berisi tentang pemberian informasi alat kelamin dan berbagai macam posisi dalam hubungan seks (Lestari dan Prasetyo, 2014). Kesimpangsiuran tentang arti pendidikan seks yang sebenarnya, menjadikan masyarakat memiliki persepsi bahwa pendidikan seks terlalu vulgar apabila diberikan pada anakanak (Justicia, 2016). Masyarakat awam cenderung memiliki anggapan bahwa pengetahuan tentang seks adalah ranah untuk orang dewasa dan anak-anak akan mengerti dengan sendirinya saat mereka dewasa.

Rahmawati (2012) menjelaskan bahwa anak yang tidak menerima pendidikan seks memiliki risiko untuk melakukan perilaku seks yang negatif di masa mendatang (remaja). Hal tersebut dikarenakan anak mencari tahu pada sumber yang tidak tepat, sehingga berpotensi mendapatkan pemahaman yang keliru tentang seks yang menyebabkan anak melakukan perilaku menyimpang (Ambarwati, 2013).

Persepsi orangtua terhadap pendidikan seks didefinisikan sebagai cara pandang (positif maupun negatif) orangtua kaitannya dengan mengajarkan dan memberikan pemahaman kepada anak tentang hal-hal yang berhubungan dengan seks sesuai pengalaman yang diperoleh orangtua (Akpama, 2013; Dyson, 2010). Pendidikan seks meliputi pengembangan self-respect pada anak, pemahaman tentang istilah seks, penanaman nilai-nilai tentang hubungan interpersonal, dan komunikasi tentang topik seks (Sule, Akor, Toluhi, Suleiman, Akpihi dan Ali, 2015).

Persepsi menjadi penting untuk diteliti dalam pendidikan seksual, karena persepsi menentukan cara pandang dan sikap pada dunianya dalam hal ini pendidikan seksual. Persepsi memungkinkan seseorang memaknai dan mengkategorikan sebuah objek untuk kemudian ditindaklanjuti menjadi sikap dan perilaku. Dalam konteks ini persepsi yang dimiliki oleh seorang ibu akan menentukan cara ibu melaksanakan pendidikannya.

Nyarko, Adentwi, Asumeng dan Ahulu (2014) mengatakan bahwa terdapat beberapa faktor yang memengaruhi sikap orangtua dalam memberikan pendidikan seks kepada anak, yaitu persepsi umum masyarakat dan sistem kayakinan sosial, faktor religi, orangtua serta pendidik. Herjanti (2015) juga mengatakan bahwa pola dan bentuk pendidikan yang diberikan oleh orangtua akan berbeda satu dengan yang lain, hal tersebut disebabkan setiap orang mendapatkan informasi dari pengalamannya secara personal.

Beberapa negara juga menerapkan pendidikan seks dengan bentuk dan tujuan yang berbeda. Swedia misalnya, yang menjadi pelopor sex education pertama di Eropa menerapkan pendidikan seks untuk mendukung dan mempersiapkan generasi muda dalam bertanggung jawab terhadap kehidupannya, terutama yang berkaitan dengan seksualitas (Kelefang, 2008). Sedangkan di Amerika pendidikan seks bertujuan untuk meningkatkan kesadaran warganya tentang perilaku seks yang sehat (Knowles, 2012).

Permasalahan yang terjadi di Indonesia kaitannya dengan pemberian pendidikan seks adalah orangtua masih merasa sungkan membicarakan topik seksual kepada anak, mereka menganggap hal tersebut tabu dan belum perlu disampaikan kepada anak (Ambarwati, 2013). Kebanyakan orangtua mengabaikan kebutuhan anak akan pendidikan seks (Esohe, 2015). Padahal pendidikan seks memberikan banyak dampak positif bagi anak, termasuk mengurangi kehamilan di usia dini dan penyakit menular seks (Kirby, 2011).

Pendidikan seks pada dasarnya memiliki tujuan untuk memberikan pengajaran dan pemahaman kepada anak tentang hal-hal yang berkaitan dengan seks, sehingga anak tidak terjerumus ke dalam pergaulan yang tidak sehat dan terhindar 
dari hal-hal negatif yang timbul akibat perilaku seksual yang keliru. Hal tersebut sesuai dengan hasil identifikasi oleh The U.S. Department of Health and Human Services yang menyatakan bahwa terdapat sebanyak 28 bukti yang merujuk pada keberhasilan program pendidikan seks sejak dini, diantaranya mencegah kehamilan dini, mengurangi jumlah perilaku hubungan seksual di bawah umur dan mengurangi perilaku seksual yang berisiko lainnya (Knowles, 2012:4).

Peran orangtua dalam memberikan pengajaran tentang seks sangat penting, terutama ibu. Sebagaimana diketahui bahwa "al-ummu madrasah al-ula" ibu merupakan madrasah pertama bagi anak. Pengetahuan ibu tentang pendidikan seks memiliki pengaruh terhadap penerapan pendidikan seks kepada anak (Ambarwati, 2013).

Untuk itu, penelitian ini melibatkan ibu sebagai subjek penelitian. Adapun lokasi yang dipilih untuk melakukan penelitian ini adalah Desa Jambesari, Kecamatan Poncokusumo, Kabupaten Malang. Pemilihan lokasi penelitian didasarkan pada banyaknya kasus pelanggaran norma seksual yang dilakukan oleh anak dan remaja.

\section{Metode Penelitian}

Penelitian ini dilakukan dengan menggunakan metode fenomenologi untuk memperoleh pemahaman tentang pandangan orangtua dalam memberikan pendidikan seks kepada anak. Pendekatan fenomenologi dipilih untuk mempermudah dalam mengungkap makna dari pendidikan seks yang dimunculkan oleh subjek. Oleh karena itu fokus dari penelitian ini adalah tentang makna pendidikan seks bagi orangtua yang dipresentasikan melalui keterlibatan orangtua dalam memberikan pendidikan seks kepada anak dan bentuk pendidikan seks yang selama ini sudah diberikan kepada anak.

Subjek dalam penelitian ini dipilih berdasarkan pertimbangan peneliti, guna mendapatkan pemahaman secara spesifik tentang problem riset dan fenomena yang terkait dalam penelitian. Penelitian ini melibatkan 5 orang ibu yang memiliki pengalaman mengasuh anak (NW, WT, SR, RP, SK). Alasan pemilihan subjek karena ibu merupakan pendidik pertama yang memberikan pendidikan kepada anak sebelum anak menerima pendidikan dari orang lain, sehingga penting untuk mengetahui pola pengasuhan mereka dalam memberikan pendidikan seks kepada anak.

Pengambilan data dilakukan peneliti dengan melakukan pendekatan kepada masyarakat, survei lapangan dan untuk memperoleh gambaran data yang valid tentang keadaan lingkungan subjek, peneliti melakukan live in di salah satu rumah warga selama satu minggu. Selama kurun waktu tersebut peneliti melakukan wawancara dan observasi terhadap subjek penelitian. Wawancara dilakukan atas persetujuan subjek dengan pemilihan tempat dan waktu yang juga didasarkan pada kesediaan subjek.

\section{Hasil Penelitian dan Pembahasan}

\section{Persepsi Orangtua Terhadap Pendidikan Seks}

Pendidikan seks merupakan istilah yang jarang ditemui di kalangan masyarakat, khususnya masyarakat desa. Kurangnya akses informasi menjadi salah satu faktor yang membuat pendidikan seks tidak dikenal oleh masyarakat. Hal tersebut sebagaimana yang diungkapkan subjek SK bahwa selama ini belum pernah ada penyuluhan tentang pendidikan seks di Desa Jambesari,

"Di sini belum pernah diadakan penyuluhan tentang pendidikan seks, orangtua zaman dulu juga tidak pernah mengajarkan tentang pendidikan seks" 


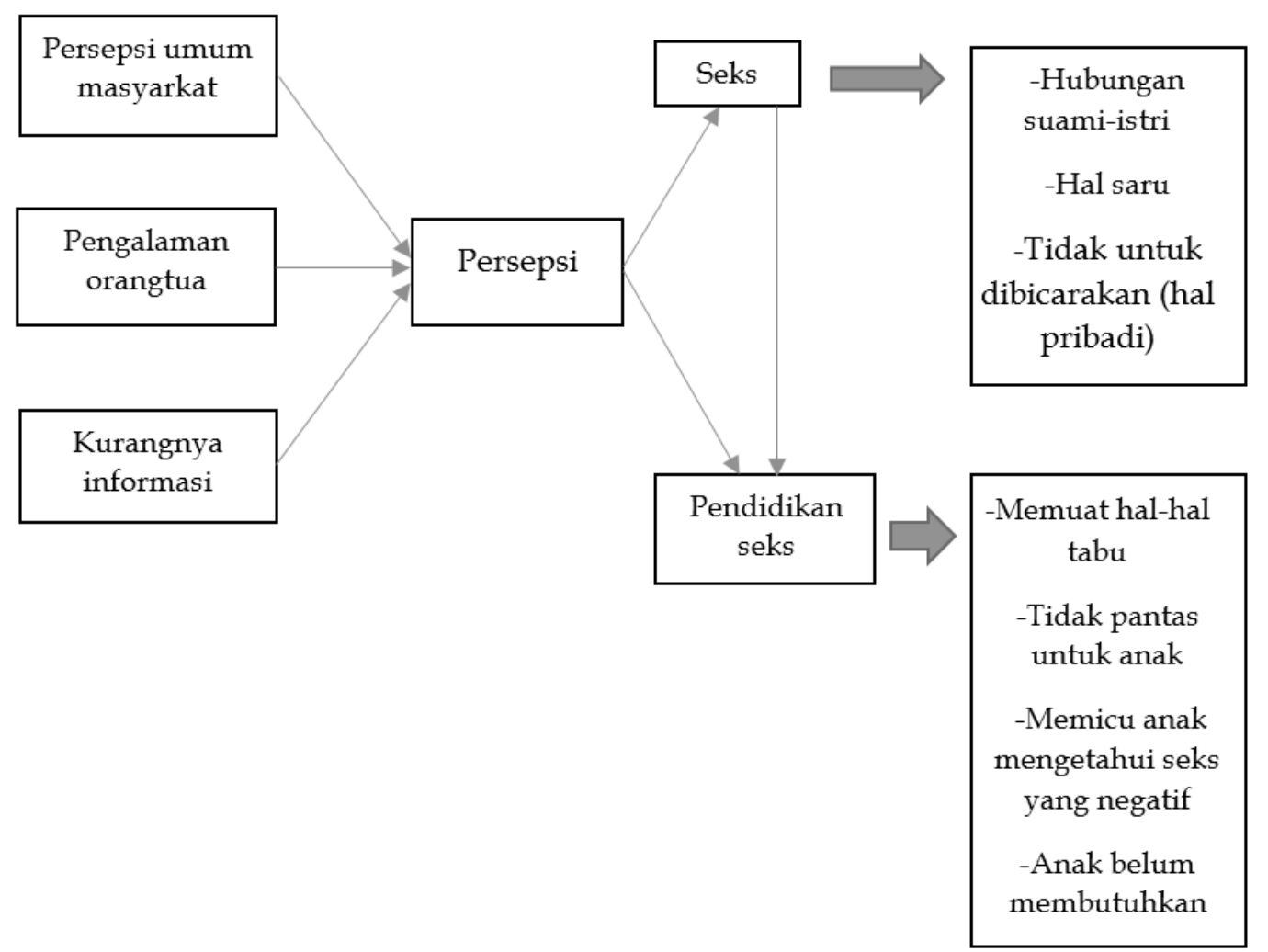

Gambar 1. Skema Persepsi orangtua terhadap pendidikan seks

Istilah seks sering diartikan sebagai hubungan antara laki-laki dan perempuan yang sifatnya pribadi, sebagaimana dikatakan:

"Pendidikan seks hal saru, karena biasanya hanya membicarakan seks dengan suami, malu jika dijelaskan kepada orang lain." (NW, SR, RP)

'Seks atau jima' itu berhubungan dengan suami-istri yang mewajibkan mandi besar, tidak etis kalau dijelaskan kepada anak." (WT)

"Pendidikan seks dapat memicu anak mengetahui tentang hubungan badan antara laki-laki dan perempuan" $(S K)$.

Definisi tersebut memunculkan anggapan saru bagi kebanyakan orang, oleh karenanya topik yang berkaitan dengan seks jarang dibicarakan di kalangan masyarakat. Hal tersebut sesuai dengan fakta di lapangan yang disampaikan subjek, bahwa masyarakat cenderung tertutup dan menghindari pembahasan tentang hal-hal yang berhubungan dengan seks, sebagaimana dikatakan :

"Di desa masalah seks itu tertutup, orang di sini malu membicarakan tentang seks, karena hal tersebut saru." (WT, SR)

Anggapan saru pada hal yang berkaitan dengan seks, menjadikan orangtua juga memiliki anggapan yang sama pada istilah pendidikan seks. Oleh karenanya orangtua tidak setuju apabila pendidikan seks diberikan kepada anak. Pendidikan seks dianggap memuat hal-hal yang tabu, sehingga orangtua cenderung menentang apabila pendidikan seks 
diberikan sejak dini, sebagaimana dikatakan :

"Saya marah jika anak diberikan penjelasan tentang hal yang saru, anak tidak seharusnya diajarkan tentang hal-hal tabu." (NW)

Orangtua beranggapan bahwa pendidikan seks akan memicu anak untuk mencari tahu tentang hal-hal yang berkaitan dengan seksualitas, disebabkan anak memiliki rasa penasaran dan keingintahuan yang tinggi, sehingga orangtua merasa khawatir apabila anak meniru perilaku seksual,

"Anak sering merasa penasaran, jika diberikan pendidikan seks bisa memicu anak mengetahui tentang hubungan seks, kemudian dipraktekkan dengan temannya." (WT, RP, $S K)$.

"Anak masih kecil, belum memahami hal yang seperti itu. Nanti setelah dewasa anak akan tahu tanpa harus diberikan pelajaran." (NW, WT, SR)

Fakta yang ditemukan di lapangan menyebutkan bahwa para subjek tidak pernah mendapatkan pengajaran tentang hal-hal yang berkaitan dengan seks dari orangtuanya, sebagaimana dikatakan :

"Orangtua zaman dulu yang
terpenting adalah mengajarkan
sholat dan mengaji, tidak pernah
memberikan pendidikan seks." (NW,
$W T, S R, R P, S K)$

"Belajar tentang seks secara mandiri, belajar dari suami." (NW, RP)

Beberapa subjek memahami topik tersebut secara mandiri saat mereka sudah menikah, sehingga pengetahuan yang mereka dapat tentang seks hanya sebatas hubungan badan antara laki-laki dan perempuan.
Untuk mempermudah memahami persepsi orangtua terhadap pendidikan seks di Desa Jambesari, Poncokusumo, Malang, disajikan dalam Gambar 1. Skema menjelaskan tentang bagaimana persepsi orangtua terhadap pendidikan seks terbentuk. Dapat dilihat bahwa terdapat beberapa faktor yang memengaruhi persepsi orangtua, yaitu persepsi umum masyarakat Jambesari yang menganggap seks merupakan hal saru dan tidak pantas untuk diperbincangkan secara umum, pengalaman orangtua yang tidak pernah mendapatkan pengajaran tentang seks sebelumnya dan kurangnya informasi seputar pendidikan seks.

Ketiga faktor tersebut membentuk pemahaman yang keliru tentang makna pendidikan seks sebenarnya. Pengertian tentang istilah pendidikan seks sebagai hal yang tabu dipengaruhi oleh makna dari istilah 'seks' yang diartikan sebagai hubungan badan antara suami-istri. Orangtua cenderung menganggap pendidikan seks memberikan informasi tentang hal tabu, seperti hubungan seksual dan hal-hal yang berhubungan dengan alat kelamin.

Anggapan tersebut membentuk persepsi orangtua bahwa pendidikan seks terlalu vulgar dan tidak pantas apabila disampaikan kepada anak. Menurut orangtua pendidikan seks dapat memicu anak untuk mengetahui dan mencari tahu tentang hal-hal yang berhubungan dengan seks, sehingga dikhawatirkan anak akan meniru perilaku seks yang negatif. Oleh karenanya orangtua berpendapat bahwa saat ini anak belum membutuhkan penjelasan tentang seks, mereka akan mengetahui dengan sendirinya ketika dewasa.

\section{Keterlibatan dan Bentuk Pendidikan Seks}

Desa Jambesari memiliki peringkat tinggi kaitannya dengan perilaku menikah di usia dini, hal tersebut sebagaimana dikatakan oleh Kepala Desa Jambesari, Poncokusumo, Malang: 
"Iya memang benar di sini menikah usia di bawah umur itu banyak, biasanya ya lulusan SD, SMP itu sudah menikah kalau di sini."

Salah satu penyebab terjadinya fenomena pernikahan dini tersebut adalah unwanted pregnancy atau hamil sebelum menikah. Sebagaimana yang disampaikan oleh Mudin Desa Jambesari, Poncokusumo, Malang:

"Banyak mbak pernikahan dini di sini, alasannya juga macem-macem, tapi kebanyakan biasanya sudah pacaran lalu yang perempuan hamil."

Peran ibu masih kurang, hal ini ditunjukkan oleh orangtua di Desa Jambesari. Mereka menganggap bahwa pendidikan seks mengandung unsur tabu, sehingga tidak pantas apabila disampaikan kepada anak. Orangtua merasa malu membicarakan hal-hal yang berkaitan dengan seks kepada anak.

Peran orangtua dalam mencegah penyimpangan perilaku pada anak hanya sebatas melakukan pengawasan kepada anak. Bentuk pengawasan yang dilakukan adalah dengan memastikan anak tetap di rumah dan tidak pergi terlalu jauh dari lingkungan rumah.

Pada subjek NW keterlibatan dalam memberikan pendidikan seks diwujudkan dalam bentuk meluangkan waktu untuk menasehati anak tentang masalah pergaulan, hal tersebut dilakukan oleh NW untuk mencegah anaknya salah dalam memilih pergaulan.

Keterlibatan subjek WT dilakukan dengan memberikan pengajaran dan pemahaman tentang hal-hal yang terjadi saat anak menginjak usia baligh. WT juga memberikan pemahaman tentang aturan batas aurat laki-laki maupun perempuan sesuai dengan panduan syari'at. Meskipun Subjek juga tidak terlalu memahami bagaimana mekanisme terjadinya proses aqil baligh.

Adapun pada subjek SR, RP dan SK bentuk keterlibatan ditunjukkan dengan melakukan pengawasan terhadap anak, serta mengenal lingkungan tempat anak bermain tanpa melakukan komunikasi tentang hal-hal yang berhubungan dengan seks.

Meskipun demikian subjek meyakini bahwa pendidikan agama dianggap sebagai cara untuk membentengi anak dari pengaruh negatif pergaulan bebas yang berakibat pada penyimpangan perilaku seksual. Sehingga orangtua memberikan pengajaran dan pemahaman tentang agama, dengan harapan mampu dijadikan sebagai batasan norma bagi anak, sebagaimana dikatakan oleh subjek NW :

\section{"Makanya penting lah ya istilahnya anak itu disuruh ngaji, sembayangnya yang bener, biar gak macem-macem. Kalau dia tahu agama kan gak mungkin macem-macem, gak berani, ingat sama dosa ya." (NW)}

\section{Faktor yang Memengaruhi Persepsi Ibu terhadap Pendidikan Seksual}

Berdasarkan temuan di lapangan, para subjek diketahui tidak pernah mendapatkan pengajaran tentang hal-hal yang berkaitan dengan seks dari orangtuanya dan masih merasa kurang dengan informasi yang dimiliki, misalnya WT :

"Saya enggak belajar khusus, saya belajarnya ya di pondok itu. ya tahutahu sendiri. Kan orangtua saya itu... ya memang saya lahir itu kayake sudah tua semua eh (tertawa). Kayak awam kalau terhadap hukum-hukum kayak gitu.

Beberapa subjek memahami topik tersebut secara mandiri saat mereka sudah menikah, sehingga pengetahuan yang mereka dapat tentang seks hanya sebatas hubungan badan antara laki-laki dan 
perempuan. Misalnya NW mengatakan, "Masalah begituan nanti juga bisa sendiri setelah menikah".

Di samping faktor pengalaman dan modelling pola asuh, kurangnya akses informasi tentang pendidikan seksual terkini juga memengaruhi persepsi dan keterlibatan orang tua pada pendidikan seks anak-anak.

Data penelitian ini menunjukkan bahwa pendidikan seks masih dianggap sebagai hal yang tabu oleh orangtua khususnya ibu. Kurangnya informasi tentang pendidikan seks menimbulkan kesimpangsiuran makna dari istilah tersebut. Menurut Justicia (2016) kesimpangsiuran tentang arti pendidikan seks yang sebenarnya menjadikan masyarakat memiliki persepsi negatif tentang pendidikan seks. Masyarakat cenderung menyamakan makna pendidikan seks dengan istilah seks itu sendiri.

Nyarko dkk. (2014) mengatakan bahwa terdapat beberapa faktor yang memengaruhi persepsi orangtua terhadap pendidikan seks, salah satu di antaranya yaitu persepsi umum masyarakat. Eko, Osuchukwu, Osonwa dan Offiong (2013) juga mengatakan bahwa di beberapa masyarakat pendidikan seks terlihat tabu dan tidak pantas untuk diperbincangkan. Masyarakat Jambesari menganggap segala sesuatu yang berkaitan dengan seks merupakan hal tabu dan tidak pantas untuk dibicarakan secara umum. Oleh karenanya sikap masyarakat cenderung tertutup pada topik pembahasan tentang seks.

Anggapan tabu yang berkembang di kalangan masyarakat menjadikan orangtua merasa malu dan enggan mendiskusikan hal-hal yang berkaitan dengan seks kepada anaknya. Anak-anak tidak diberikan pendidikan seks disebabkan alasan cultural yang menganggap pendidikan seks tidak penting dan melanggar adat kesopanan (Odek, 2006). Anggapan tersebut juga membuat orangtua merasa ragu untuk memberikan pendidikan seks kepada anak (Coleman dan Charles, 2009).
Pengalaman orangtua juga menjadi faktor yang memengaruhi persepsinya terhadap pendidikan seks. Hal tersebut disebabkan setiap orangtua memiliki latar belakang dan pengalaman tentang seks yang berbeda. Herjanti (2015) mengemukakan bahwa salah satu cara memperoleh pengetahuan adalah berdasarkan pengalaman yang pernah dialami di masa lalu.

Alasan lain pendidikan seks tidak sesuai bila diberikan kepada anak, karena anak belum memahami tentang topik yang berkaitan dengan seksualitas, sehingga anak tidak membutuhkan penjelasan tentang topik tersebut. Orangtua memiliki anggapan bahwa anak akan mengetahui dengan sendirinya ketika mereka tumbuh dewasa.

Orangtua merupakan sekolah pertama bagi anak, karena anak pertama kali mendapat pendidikan dari orangtuanya, hal tersebut menjadikan keterlibatan orangtua dalam memberikan pendidikan seks sangat penting untuk menjalankan fungsinya sebagai pendidik pertama dan utama bagi anak.

Zelnik dan Kim (1982) mengungkapkan bahwa jika orangtua bersedia mendiskusikan seks dengan anaknya, maka anak cenderung menunda perilaku seksual premarital. Ambarwati (2013) juga menjelaskan bahwa terdapat hubungan positif yang signifikan antara pengetahuan ibu tentang pendidikan seks dengan penerapan pendidikan seks pada anak. Nyarko dkk. (2014) menjelaskan bahwa pendidikan seks merupakan pendidikan yang memiliki tujuan untuk mengurangi potensi risiko akibat perilaku seksual yang negatif. Beberapa perilaku seksual yang negatif adalah free sex, unwanted pregnancy, dan early marriage.

Kenyataannya pada zaman sekarang, mencegah perilaku seks yang menyimpang tidak cukup hanya dengan memberikan pendidikan tentang agama saja, namun dibutuhkan pengajaran yang lebih komunikatif dan interaktif dalam menyampaikan 
informasi terkait seks kepada anak. Menurut Ololade, Ibukunoluwa, Titilayo dan Saratu (2014) menyatakan bahwa pengasuhan orangtua yang permisif dalam memberikan pendidikan seks meningkatkan risiko anak melakukan premarital sex atau hubungan seks sebelum menikah.

Perlunya keterlibatan orangtua dalam memberikan pendidikan seks dapat mengurangi risiko perilaku seks yang negatif di kalangan anak-anak. Hal tersebut disebabkan pendidikan seks memberikan pemahaman tentang batasan yang boleh dan tidak boleh dilakukan, sehingga anak terhindar dari tindakan yang seharusnya tidak dilakukan karena ketidaktahuannya (Crisalli, 2010).

\section{Simpulan dan Saran}

Penjelasan di atas menunjukkan bahwa penafsiran yang keliru tentang pendidikan seks diperoleh dari lingkungan. Sebagian besar masyarakat Jambesari menganggap pendidikan seks adalah hal negatif sehingga tidak patut untuk diberikan, terlebih kepada anak-anak. Anggapan negatif tersebut dibangun karena masyarakat kekurangan informasi tentang pendidikan seks, sehingga stimulus yang didapatkan oleh orangtua tentang pendidikan seks adalah hal-hal tabu yang tidak pantas untuk dibicarakan dengan anak-anak.

Persepsi negatif tentang pendidikan seks pada anak menimbulkan konsekuensi perilaku orangtua yang menolak terhadap pemberian pendidikan seks kepada anak, sehingga orangtua cenderung kurang dalam keterlibatan dan melakukan pengawasan kepada anak. Hal tersebut berisiko terhadap tingginya pergaulan bebas, pernikahan dini dan kehamilan yang tidak diinginkan di Desa Jambesari.

Saran dari hasil penelitian tersebut diharapkan lembaga desa untuk mengadakan program penyuluhan tentang pendidikan seks kepada masyarakat. Sedangkan untuk peneliti selanjutnya diharapkan untuk membahas tentang latar belakang pendidikan dan kondisi ekonomi orangtua sebagai faktor yang memengaruhi persepsi orangtua terhadap pendidikan seks.

\section{Daftar Pustaka}

Akpama, E.G. (2013). Parental Perception of Teaching of Sex Education to Adolescent in Secondary School in Cross River State, Nigeria, Journal of Research \& Method in Education, 1(3), 31-34.

Ambarwati, R. (2013). Peran Ibu dalam Penerapan Pendidikan Seksual pada Anak Usia Pra Sekolah, Wonosobo: Prosiding Konferensi Nasional PPNI Jawa Tengah, Hal. 197-201.

Coleman, H. \& Charles, G. (2009). Sexual Behavior and Development in Young Children, Canada: The National Child Traumatic Stress Network.

Counterman, L. \& Kirkwood, D. (2013). Understanding Healthy Sexuality Development in Young Children, NAEYC. www.naeyc.org

Crisalli, L. (2010). The Early Educator's Role in the Prevention of Child Sexual Abuse and Exploitation, Child Beginning Workshop Child Sexual Abuse.

www.childcareexchange.com

Dyson, S. (2010). Parents and Sex Education: Parents' Attitude to Sexual Health Education in WA Schools, Melbourne: Australian Research Center in Sex, Health and Society.

Eko, J.E., Osuchukwu, N.C., Osonwa, O.K., \& Offiong, D.A. (2013). Perception of Students' Teachers' and Parents' towards Sexuality Education in Calabar South Local Government Area of Cross River State, Nigeria, Journal of Sociological Research, 4(2), 225-240, ISSN 1948-5468 2013.

Esohe, K. (2015). Parents Perception of the Teaching of Sexual Education in Secondary Schools in Nigeria, 
International Journal of Innovative Science, Engineering \& Technology, 2(1), 89-99.

Herjanti. (2015). Pola Asuh Orang Tua tentang Pendidikan Seks, Jurnal Ilmu Kebidanan Indonesia, Halaman 93106.

Justicia, R. (2016). Program Underwear Rules untuk Mencegah Kekerasan Seksual Pada Anak Usia Dini, Jurnal Pendidikan Anak Usia Dini, 9(2), 217-232.

Kelefang, B. (2008). Sexuality Education in Sweden: A Study Based on Research and Young People's Service Providers in Gothenburg, Department of Social Work. Page 147.

Kirby, D. (2011). The Impact of Sex Education on The Sexual Behavior Young People, New York: United Nations, Department of Economic and Social Affairs. No 2011/12, hal. 1-19.

Knowles, J. (2012). Sex Education in United States, New York: Katharine Dexter McCormick Library and Education Division of Planned Parenthood Federation of America. Page 1-13.

Lestari, E. \& Prasetyo, J. (2014). Peran Orang Tua dalam Memberikan Pendidikan Seks Sedini Mungkin Di Tk Mardisiwi Desa Kedondong Kecamatan Kebonsari Kabupaten Madiun, NUGROHO-Jurnal Ilmiah Pendidikan, 2(2), 124-131.

Nyarko, K., Adentwi, K.I., Asumeng, M., \& Ahulu, L.D. (2014). Parental Attitude towards Sex Education at the Lower Primary in Ghana, International Journal of Elementary Education, 3(2), 21-29.
Odek, T. (2006). Cultural Challenges and Sex Education in Mageta Island, Kenya, Kenya: Afrika Regional Sexuality Resource Centre. Page 126.

Ololade, O., Ibukunoluwa, A., Titilayo, O., \& Saratu, A. (2014). Sexuality Education in Christian Homes: Knowledge and Perception of Young People in Ife Central Local Government Osun State, International Journal of Science and Research, 5(2), 697-700.

Rahmawati, N. (2012). Gambaran Perilaku Seksual pada Anak Usia Sekolah Kelas 6 Ditinjau dari Media Cetak dan Media Elektronik, Jurnal Keperwatan Masyarakat.

Sule, H.A., Akor, J.A., Toluhi, O.J., Suleiman, R.O., Akpihi, L., \& Ali, O.U. (2015). Impact of Sex Education in Kogi State, Nigeria, Journal of Education and Practice, 6(3), 34-41.

Zelnik, M. \& Kim, Y.J. (1982). Sex Education and Its Association with Teenage Sexual Activity, Pregnancy and Contraceptive Use, Family Planning Perspectives, 14, 117-119.

https://www.gatra.com/hukum-1/52038kpai-pelecehan-seksual-akibatrendahnya-kesadaran-perlindungananak.html (diakses pada 2 Desember 2016)

http://www.kpai.go.id/berita/kpaipelecehan-seksual-pada-anakmeningkat-100/ (diakses pada 2 Desember 2016) 
Psympathic, Jurnal Ilmiah Psikologi Desember 2017, Vol. 4, No. 2, Hal : 157 - 166 